医療現場の視点から：リバーストランスレーショナルリサーチとしての薬剤疫学

川上純一

\title{
From a Viewpoint of Clinical Settings: Pharmacoepidemiology as Reverse Translational Research (rTR)
}

\author{
Junichi Kawakami \\ Department of Hospital Pharmacy, Hamamatsu University School of Medicine; \\ 1-20-1 Handayama, Higashi-ku, Hamamatsu 431-3192, Japan.
}

(Received October 17, 2016)

\begin{abstract}
Clinical pharmacology and pharmacoepidemiology research may converge in practise. Pharmacoepidemiology is the study of pharmacotherapy and risk management in patient groups. For many drugs, adverse reaction (s) that were not seen and/or clarified during research and development stages have been reported in the real world. Pharmacoepidemiology can detect and verify adverse drug reactions as reverse translational research. Recently, development and effective use of medical information databases (MID) have been conducted in Japan and elsewhere for the purpose of post-marketing safety of drugs. The Ministry of Health, Labour and Welfare, Japan has been promoting the development of 10-million scale database in 10 hospitals and hospital groups as "the infrastructure project of medical information database (MID-NET)". This project enables estimation of the frequency of adverse reactions, the distinction between drug-induced reactions and basal health-condition changes, and usefulness verification of administrative measures of drug safety. However, because the database information is different from detailed medical records, construction of methodologies for the detection and evaluation of adverse reactions is required. We have been performing database research using medical information system in some hospitals to establish and demonstrate useful methods for post-marketing safety. In this symposium, we aim to discuss the possibility of reverse translational research from clinical settings and provide an introduction to our research.
\end{abstract}

Key words_— clinical research; pharmacoepidemiology; medical information database; reverse translational research

\section{1. 医療情報データベースを用いた薬剤疫学研究}

医薬品使用や薬物治療における問題点の解決法に は様々なアプローチ法がある。その中でも医療現場 においては, 臨床薬理学や薬剤疫学などの臨床研究 が実施されている。薬剤疫学とは，集団としての患 者群における薬物治療やリクス管理に関する研究で ある. 多くの医薬品において研究開発時には見い出 されなかつたり，明確になかつた副作用が実臨床に おいて報告される。そのような副作用を検出・検証 できる薬剤疫学は 1 つのリバーストランスレーショ ナルリサーチと考えられる.

近年, 医薬品の市販後安全対策等のための医療情

浜松医科大学医学部附属病院薬剂部（干431-3192 浜松 市東区半田山 1-20-1)

e-mail: kawakami-ham@umin.ac.jp

本総説は, 日本薬学会第 136 年会シンポジウム S01 で 発表した内容を中心に記述したものである。
報データベース（DB）の整備や利活用が国内外に おいて検討されている。 大規模な医療情報 DB の必 要性としては，現在の副作用報告には，医薬品が投 与されている全人数の把握, 他薬物との比較, 原疾 患と副作用の鑑別などの点で限界がある。米国にお いては，食品医薬品局 (U.S. Food and Drug Administration；FDA）の国家戦略として 2008 年 5 月 よりセンチネル・イニシアチブが開始されている. これは大規模（1 億人）な医療情報データベースを 構築して, 医薬品による副作用などを網羅的かつ迅 速に調査・解析して安全対策に活用する事業である.

日本においても厚生労働省では「医療情報デー夕 ベース基盤整備事業（Medical Information Database Nerwork; MID-NET)」として, 全国 10 病院 群において 1000 万人規模のデータベース構築を進 めている. この事業を通じて, 副作用頻度の推定, 医薬品による副作用と薬剂性ではない健康状態の変 
化との判別，そして医薬品安全対策に係る行政措置 の有用性検証が可能になると考えられる. しかし， データベース情報は詳細な診療録とは異なるため, 副作用の検出や評価のための方法論の構築が必要で ある。

われわれは, 複数の病院における医療情報システ ムを用いて，市販後安全性対策のための利活用方法 の確立と実証を目的としたデータベース研究を行っ ている．本シンポジウムではその一部を紹介すると ともに，医療現場からのリバーストランスレーショ ナルリサーチの可能性について記す。

2. 副作用検出アルゴリズムの構築及び行政施策 の医療現場における反映・効果に関する研究の例

筆者が研究代表者を務めた 2011 年度からの厚生 労働科学研究費補助金 (医薬品・医療機器等レギュ ラトリーサイエンス総合研究事業）「医薬品等の市 販後安全対策のための医療情報データベースを活用 した薬剂疫学的手法の確立及び実証に関する研究」 の分担研究として標記の研究を実施した. ${ }^{1,2)}$

浜松医科大学病院医療情報データベースを使用し た. 副作用検出アルゴリズムの構築については, 2008-2011 年度の症例データを対象とし，ヘパリン 起因性血小板減少症 II 型（heparin-induced thrombocytopenia；HIT）の検出を試夕た．HIT 疑(症例 を検出するアルゴリズムを作成し，スコアリングシ ステムと血液内科医のカルテレビューにより精度評 価を行った。HITのリスク因子を多重ロジス ティック回帰分析した。行政施策の効果確認につい ては，オセルタミビルリン酸塩の 10 代原則使用制 限（2007 年 3 月に緊急安全性情報を発出）と, ク ロピドグレル (clopidogrel; CPG) とオメプラゾー ル (omeprazole; OPZ) との併用注意（2010 年 4 月に添付文書改訂を通知）の 2 事例について処方動 向を調べた。前者に関しては，2002 年 4 月から 2011 年 3 月末までの各シーズンで, 年齢層毎に通 知前後の処方患者の推移を解析した. 後者に関して は，通知前後の 1 年間における $\mathrm{CPG}$ と $\mathrm{OPZ}$ を含 むプロトンポンプインヒビター (proton pump inhibitor；PPI）との併用状況を解析した.

HIT 検出アルゴリズムの構築については, 未分 画ヘパリン投与患者数は 2875 人であり，そのうち HIT 疑いは 47 人であった. 医師のカルテレビュー により 41 人が確定症例であり，アルゴリズムの陽

性的中率（positive predictive value; PPV) は $87.2 \%$ （95\% CI：74.8-94.0） であった. HIT 確定症例の発 現頻度は $1.4 \%$ であった。発症リスク因子として 4 日以上の投与について有意な差が認められ（ $p<$ 0.0001)，そのオッズ比は 5.38 (95\% CI: 2.35-12.32) であった．行政施策の効果確認については，オセル タミビルの処方割合は，20 歳以上の患者では有意 な変化はなかったが，10 代の患者では施策後には $76.4 \%$ 減少した $(p=0.0011) . C P G$ 処方患者のう ち OPZ 併用例の割合は有意に変化しなかったが, 類薬であるランソプラゾール又はラベプラゾール併 用例の割合が施策後に $1.56 \% /$ 月の率で増加した $(p=0.0025)$.

PPV が高く有用性の期待できる HIT 検出アルゴ リズムが構築でき，データベース活用手法の実用性 を示すことができた．また，医療情報データベース を用いた行政施策の効果確認を目的とした薬剤疫学 的な評価方法を検討し，具体的事例を基にその実効 性を示すことが可能であったと考える.

\section{3. 医薬品による副作用検出と対照薬との比較研} 究の例

ニューキノロン系抗菌薬による腱障害はアメリカ やオセアニアではよく知られており添付文書等で注 意喚起されている。しかし国内ではいくつかの症例 報告があるが発現頻度は明らかになっていない。本 研究では, 浜松医科大学医学部附属病院の診療情報 データベースを使用し，内服セファロスポリン系抗 菌薬の処方患者を対照としてニューキノロン抗菌薬 による腱障害の発現リスクを評価した. ${ }^{3)}$

1996 年 4 月から 2009 年 12 月の期間に, ニュー キノロン抗菌薬は 17147 人に処方され，14 名で腱 障害が発現した（頻度 $0.082 \% ， 95 \%$ 信頼区間 CI: 0.049-0.137)。その頻度はセファロスポリン系抗菌 薬の処方患者における腱障害の発現（処方 38517 人, 腱障害 5 名，頻度 $0.013 \% ， 95 \% \mathrm{CI} ： 0.006-$

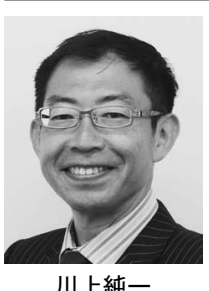

川上純一
平成 2 年東京大学薬学部卒業, 4 年同 大学院薬学系研究科修士課程修了, 7 年同博士課程修了. 7 年東京大学医学 部附属病院薬剂部助手, 10 年オラン ダ・ライデン大学客員研究員, 12 年富 山大学助教授 - 附属病院副薬剂部長, 18 年浜松医科大学教授 - 医学部附属病 院薬剂部長 (現職), 19 年静岡県立大 学薬学部客員教授. 
0.030) よりも有意に高かった $(p<0.001)$. セファ ロスポリン系抗菌薬の処方患者に対するニューキノ ロン抗菌薬の処方患者における腱障害の発現頻度比 は 6.29 倍（95\%CI: 2.27-17.46） であった。 14 名 の年齢範囲 38-95 歳, 平均 63 歳であり, 男性 8 名 だった. 投与量は承認投与量を超える例はなかった.

3 名が腱断裂，11 名が腱炎及び腱周囲炎だった。 12 名はニューキノロン抗菌薬の投与は 2 週間以内であ り，11 名は計算上の服用終了日から 2 週間以内に 腱障害を発現した。

以上より，診療情報データベースを用いてニュー キノロン抗菌薬による腱障害の副作用を検出し, 症 例を同定してその背景について検討することができ た。この方法は低頻度で自発報告されない副作用を 検出する方法として有用な一手段であると考えられ る.

\section{4. 医療情報 DB を用いた副作用検出手法・薬剤} 疫学研究

上記以外にも, チクロピリジン・チアマゾール等 による薬剤性無顆粒球症や白金抗がん剂による聴覚 障害などの副作用について，医療情報 DB を用いた 検出を試みており， 80-90\%以上の高い陽性的中率 を見い出している．医療情報 DB を用いることで， 時間経過によるデータの蓄積により，より少ない時 間的・費用的負担で多人数のデー夕を得ることがで きる。一方で，処方と実際の服用との乘離や，一部 の患者情報（身長・体重，喫煙歴など）は得られな い場合もある。

医療情報 DB を副作用の調查・研究等に 2 次利用
する際には，その種類による特徵も重要となる。例 えば，保険者情報ベースの DB は，診療を受けた施 設を問わないことや，データが標準化されているメ リットがある。一方，病院情報べースの DB では， 処方内容や検査結果を含めたデー夕が入手可能であ り，診療録を閲覧することも可能である。これらの 特性を有する医療情報 DB を用いた医薬品の副作用 検出や安全対策等に関する薬剂疫学研究は，これか らの薬学研究の 1 つの柱になると考える.

謝辞本研究の一部は国立研究開発法人日本医 療研究開発機構 (AMED) の平成 26-27 年度医薬 品等規制調和・評価研究事業「医薬品等の市販後安 全対策のための医療情報データベースの利活用方法 に関する薬剤疫学研究」の支援により行われた.

利益相反＼cjkstart開示すべき利益相反はない.

\section{REFERENCES}

1) Hanatani T., Sai K., Tohkin M., Segawa K., Kimura M., Hori K., Kawakami J., Saito Y., J. Clin. Pharm. Ther., 38, 423-428 (2013) .

2) Hanatani T., Sai K., Tohkin M., Segawa K., Antoku Y., Nakashima N., Yokoi H., Ohe K., Kimura M., Hori K., Kawakami J., Saito Y., J. Clin. Pharm. Ther., 39, 361-367 (2014) .

3) Hori K., Yamakawa K., Yoshida N., Ohnishi K., Kawakami J., Pharmacoepidemiol. Drug Saf., 21, 886-889 (2012). 